\title{
11
}

\section{Bacterial Respiration of Arsenate and Its Significance in the Environment}

\author{
Ronald S. Oremland \\ U.S. Geological Survey, Menlo Park, California \\ Dianne K. Newman \\ California Institute of Technology, Pasadena, California \\ Brian W. Kail and John F. Stolz \\ Duquesne University, Pittsburgh, Pennsylvania
}

\section{INTRODUCTION}

Although arsenic is a trace element in terms of its natural abundance, it nonetheless has a common presence within the earth's crust. Because it is classified as a group VB element in the periodic table, it shares many chemical and biochemical properties in common with its neighbors phosphorus and nitrogen. Indeed, in the case of this element's most oxidized (+5) oxidation state, arsenate $\left[\mathrm{HAsO}_{4}{ }^{2-}\right.$ or As (V)], its toxicity is based on its action as an analog of phosphate. Hence, arsenate ions uncouple the oxidative phosphorylation normally associated with the enzyme glyceraldehyde 3-phosphate dehydrogenase, thereby preventing the formation of phosphoglyceroyl phosphate, a key high-energy intermediate in glycolysis. To guard against this, a number of bacteria possess a detoxifying arsenate reductase pathway (the $\operatorname{ars} C$ system) whereby cytoplasmic enzymes remove internal pools of arsenate by achieving its reduction to arsenite $\left[\mathrm{H}_{2} \mathrm{AsO}_{3}{ }^{-}\right.$or As (III)]. However, because the arsenite product binds with internal sulfhydryl groups that render it even more toxic than the original arsenate, efficient arsenite efflux from the cell is also required and is achieved by an active ion "pumping" 
system (1). The details of this bacterial arsenic detoxification phenomenon have been well established in the literature, and Chapter 10 in this volume provided a thorough review. Here, we discuss bacterial respiration of arsenate and its significance in the environment. As a biological phenomenon, respiratory growth on arsenate is quite remarkable, given the toxicity of the element. Moreover, the consequences of microbial arsenate respiration may, at times, have a significant impact on environmental chemistry.

Much less is understood about the mechanisms of microbial arsenate respiration than about the mechanisms of arsenate detoxification, although these processes face similar challenges, namely: the transport of arsenate into the cell, its reduction to arsenite, the protection of intracellular proteins from arsenite, and the export of arsenite out of the cell. In the case of arsenate-respiring microorganisms, the nature of arsenic transport across the cell membrane is as yet unclear, and we must look to arsenic-resistant organisms as our initial models. Presumably, for gram-negative bacteria, arsenate enters the cells through nonspecific outer-membrane porins, or, in the case of phosphate starvation, through inducible outer-membrane proteins that are designed for phosphate transport but cannot discriminate between arsenate and phosphate (such as PhoE) (2). Upon reaching the periplasm, arsenate may be reduced to arsenite by respiratory reductases (see below) or further transported into the cytoplasm, as is known to occur in Escherichia coli and presumably in other As-resistant organisms. Under conditions of phosphate abundance $(>1 \mathrm{mM})$, arsenate can enter the cytoplasm through a low-affinity phosphate transport system (Pit). In E. coli, pitA is constitutively expressed and couples uptake of inorganic phosphate to the proton motive force (3). In strains dependent on Pit for inorganic phosphate uptake, exposure to arsenate leads to the depletion of intracellular adenosine triphosphate (ATP) stores and the intracellular accumulation of arsenate, demonstrating the direct interference of arsenate in phosphate metabolism (4).

Despite the similarity between arsenate and phosphate, organisms have evolved ways to discriminate between the two compounds. For example, mutations in pitA lead to the induction of the high-affinity phosphate transport system (Pst), which differentiates between arsenate and phosphate approximately 100fold more accurately than PitA. The key components of the Pst system include PstS, PstA, PstB, and PstC. PstS is a periplasmic protein that hinds inorganic phosphate with high selectivity and carries it to the high-affinity phosphate transporter (located in the cytoplasmic membrane) comprised of PstA, PstC, and PstB. Transport of phosphate through this complex is coupled to ATP hydrolysis at PstB, making transport of phosphate through the Pst system more costly for the cell than through Pit (2). The switch from the low- to high-affinity phosphate transport systems results in moderate arsenate tolerance (5). Whether arsenaterespiring organisms also rely on phosphate transport systems to uptake arsenic or have evolved arsenate-specific transporters remains an open question. 
Once inside the cell, arsenate ions can be reduced to arsenite via membranebound or cytoplasmic enzymes. The former are linked to cellular energy conservation and are described in detail later in this chapter and in Chapter 12; the latter are characteristic of As-resistant microbes, do not conserve energy, and have been described in Chapter 10. Before detailing the bioinorganic chemistry of arsenic by micro-organisms, however, we will briefly discuss the incorporation of arsenic into organic compounds. For more details on this subject, we refer the reader to comprehensive reviews by Phillips (6) and Reimer (7).

Depending upon the organism, inorganic arsenic ultimately may be converted into arsenosugars as well as a variety of methylated species. The occurrence of this phenomenon in plants and algae is highly variable. Internal arsenic pools occurring in mosses, for example, are dominated by inorganic species as opposed to organic compounds (8). Once inside the cell, however, arsenate may undergo further reduction to a lower redox state (arsine) where it is incorporated into organic matter in a fashion analogous to that of quaternary nitrogen compounds. For example, arsenobetaine is an analog of the internal osmolyte glycine betaine commonly found in marine organisms (Fig. 1). Arsenobetaine commonly occurs in a variety of marine animals (9), as well as in bacteria found in the arsenic-rich waters of hypersaline Mono Lake, California (10). In the latter case, arsenobetaine may serve a dual purpose of functioning not only as a compatible internal solute in an environment of high osmotic stress, but also as a mechanism for converting potentially toxic internal pools of arsenate and arsenite into an innocuous organic compound. Animals presumably obtain their organoarsenic compounds from the food chain, by eating As-containing plants and algae. The occurrence of organoarsenicals in the tissues of deep-sea hydrothermal vent ani-

\section{$\mathrm{CH}_{3}$ \\ $\mathrm{CH}_{3}-\mathrm{N}^{(+)}-\mathrm{CH}_{2} \mathrm{COO}^{(-)}$ \\ $\mathrm{CH}_{3}$ \\ glycine betaine

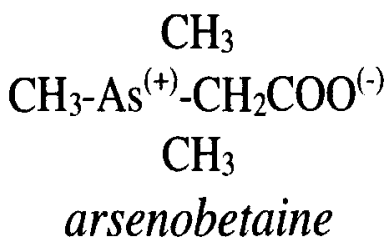

Figure 1 Molecular structure of the osmolyte glycine betaine and its analog arsenobetaine. 
mals suggests that it is also possible for animals to obtain arsenic from autotrophic and/or symbiotic bacterial sources rather than phytoplankton (11). Neff (12) has reviewed the toxicology of various arsenic species in marine ecosystems.

A number of micro-organisms isolated from sediments, macroalgae, and the intestinal tract of chitons have been shown to degrade arsenobetaine to trimethylarsine oxide $\left[\left(\mathrm{CH}_{3}\right)_{3} \mathrm{AsO}\right]$, dimethylarsinic acid $\left[\left(\mathrm{CH}_{3}\right)_{2} \mathrm{AsO}(\mathrm{OH})\right]$, methylarsonic acid $\left[\mathrm{CH}_{3} \mathrm{AsO}(\mathrm{OH})_{2}\right]$, arsenite, and arsenate. In this pathway, arsenic is oxidized back to the +5 state $(9)$. In anoxic environments, glycine betaine is cleaved to form acetate and trimethylamine, both of which may enter methanogenic degradation pathways (13). Little is known about the occurrence of trimethylarsine in nature, although methylated arsenic compounds with arsenic in the +5 oxidation state have been detected in the aerobic regions of a number of water bodies (14), presumably from aerobic degradation of arsenobetaine or from partial oxidation of methyl arsines. Methanogenic attack of trimethylarsine would result in the formation of highly toxic arsine gas $\left(\mathrm{AsH}_{3}\right)$ rather than ammonia. Relatively little is known about the biogeochemical cycling of organoarsenic compounds in the aerobic or anaerobic environments, making this an area ripe for future investigation.

Although the ars $C$ system of bacterial arsenate resistance and the decomposition of organoarsenic compounds represent potential mechanisms whereby reduced inorganic arsenic species (arsenite or arsine) can accumulate in an external aqueous milieu, neither process conserves energy or offers any special evolutionary advantage to the cells other than survival in a toxic aquatic matrix. It was the report by Ahmann et al. (15) in 1994 that first recognized arsenate as an anaerobic terminal electron acceptor capable of supporting the respiratory growth of new species of Eubacteria. The discovery of this phenomenon has implications across several disciplines of environmental importance, including microbiology, biochemistry, toxicology, and geochemistry, and is the subject of three recent succinct revicws $(16-18)$. Because this is a fast-emerging field and the phenomenon may ultimately impact the health of large human populations in such regions as the Ganges delta of Banagladesh and India (19), we have written this chapter to further update and summarize recent findings.

\section{MICROBIOLOGY AND BIOCHEMISTRY OF ARSENATE RESPIRATION}

Currently, in pure culture, there are seven novel species of Eubacteria, most of them isolated from arsenic-rich environments (20-27), that are capable of respiring arsenate (Table 1). Although this is only a small number of representative species, it is already clear that the phenomenon is polyphyletic. It occurs in both gram-positive (low $\mathrm{G}+\mathrm{C}$ ) Eubacteria and in at least three subdivisions (delta, 
Table 1 Novel Bacterial and Archaeal Isolates That Can Grow by Respiratory Arsenate Reduction

\begin{tabular}{llc}
\hline Microbe & \multicolumn{1}{c}{ Classification } & Refs. \\
\hline Sulfurospirillum arsenophilum & E-Proteobacteria & 15,20 \\
Sulfurospirillum barnesii & E-Proteobacteria & $20,21,22$ \\
Chrysiogenes arsenatis & Deep-branch Proteobacteria & 23 \\
Desulfotomaculum auripigmentum & Low G + C gram positive & 24,25 \\
Bacillus arsenicoselenatis & Low G + C gram positive & 26 \\
Bacillus selenitireducens & Low G + C gram positive & 26 \\
Desulfovibrio Ben-RB & D-Proteobacteria & 27 \\
Pyrobaculum arsenaticum & Crenoarchaea & 28 \\
\hline
\end{tabular}

epsilon, and gamma) of the gram-negative Proteobacteria, along with another deeply branching representative (Chrysiogenes). Preliminary evidence suggests that a marine strain of Shewanella sp. also respires arsenate (D. K. Newman, personal communication). Until quite recently there were no reports of Archaea that respire arsenate, although the elevated concentrations of arsenic commonly occurring in hot springs and in some hypersaline lakes suggests a niche in which arsenate-respiring Crenoarchaea and Haloarchaea patiently await discovery. Recently, Huber et al. (28) reported on the ability of a newly isolated hyperthermophilic Crenoarchaea, Pyrobaculum arsenaticum, to respire arsenate. Examination of three other members of this genus revealed that one of them, $P$. aerophilum, was also capable of arsenate respiration. Both organisms are facultative autotrophs, being able to grow by respiring arsenate with $\mathrm{H}_{2}$ as the electron donor and $\mathrm{CO}_{2}$ as the source of cell carbon. Two organisms, Bacillus arsenicoselenatis and $B$. selenitireducens are extremophiles adapted to the high $\mathrm{pH}$ and salinity of Mono Lake, California. As yet, there are no reports of extreme acidophilic Archaea or Bacteria that respire arsenic. However, the high concentrations of arsenic in the waters of Iron Mountain, California (29) and the occurrence of mats of iron-oxidizing Archaea in this system (30) would suggest the presence of arsenic-oxidizing and -reducing Archaea as well.

All of the Eubacterial arsenate-respirers reduce arsenate quantitatively to arsenite. No significant gaseous products (methylated arsines or $\mathrm{AsH}_{3}$ ) or elemental arsenic are produced. None of the arsenate respirers currently in culture are obligate arsenate-reducers, and all exhibit various degrees of flexibility with regard to their ability to use electron acceptors other than arsenate. For example, most can use nitrate, three can use selenium oxyanions, two are microaerophiles, and two are sulfate-reducers. Dissimilatory nitrate reduction by Sulfurospirillum barnesii results in the formation of ammonium rather than $\mathrm{N}_{2}(21)$. Desulfotoma- 

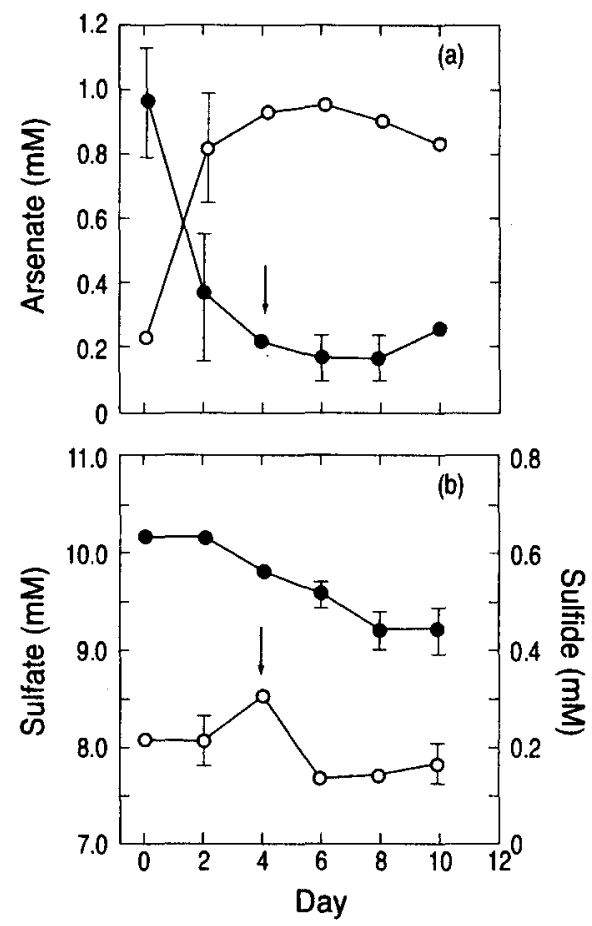

Figure 2 Sequential reduction of (a) arsenate and (b) sulfate during growth of Desulfotomaculum auripigmentum. (From Ref. 24.)

culum auripigmentum respires arsenate first, followed by sulfate (Fig. 2), resulting in the precipitation of yellow arsenic trisulfides and the mineral orpiment (24,25). The precedence of As( V) before sulfate can be explained by the higher energy yield $\left(\Delta \mathrm{G}^{\prime}\right)$ associated with the oxidation of a given electron donor $\left(\mathrm{H}_{2}\right)$ with arsenate $\left(-23.03 \mathrm{~kJ} / \mathrm{mol} \mathrm{e}^{-}\right)$as opposed to sulfate $\left(-0.42 \mathrm{~kJ} / \mathrm{mol} \mathrm{e}^{-}\right)(16)$. However, Desulfomicrobium strain Ben-RB exhibits concurrent reduction of arsenate and sulfate, suggesting that there are considerable physiological differences that factor into this phenomenon as well (27).

Growth of $B$. arsenicoselenatis on lactate results in its oxidation to acetate plus $\mathrm{CO}_{2}$ with the reduction of arsenate to arsenite (Fig. 3). Growth conforms to the equation:

$$
\begin{aligned}
\text { lactate } & +2 \mathrm{HAsO}_{4}{ }^{-}+\mathrm{H}^{+} \\
& \rightarrow \text { acetate }^{-}+2 \mathrm{H}_{2} \mathrm{AsO}_{3}^{--}+\mathrm{HCO}_{3}^{-} \Delta \mathrm{G}_{f}^{\prime \prime}=-23.4 \mathrm{~kJ} / \mathrm{mole}^{-}
\end{aligned}
$$




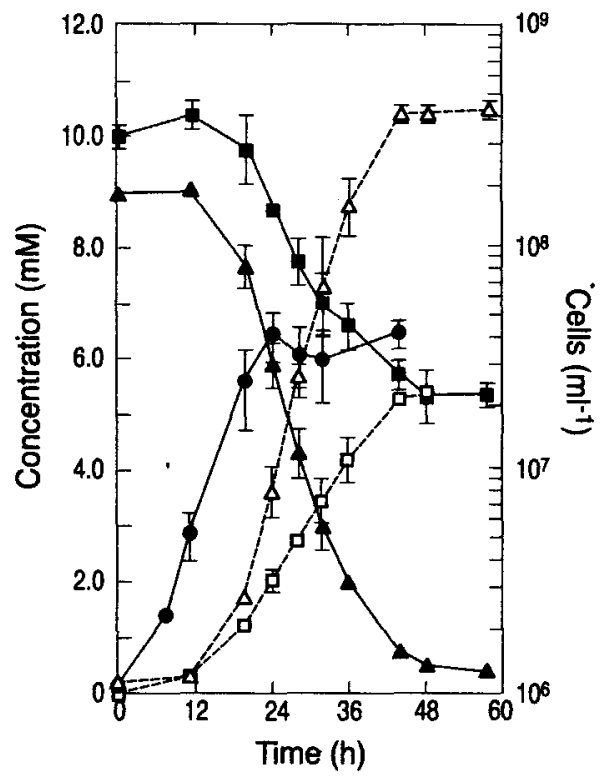

Figure 3 Growth of Bacillus arsenicoselenatis with lactate as its electron donor and arsenate as its electron acceptor. Symbols: $\boldsymbol{\Lambda}$, arsenate; $\triangle$, arsenite; $\boldsymbol{\square}$, lactate; $\square$, acetate; , cells. (From Ref. 26.)

Therefore, the reduction of arsenate is highly exergonic, although it is not nearly as potent an oxidant as are selenate, nitrate, or manganic ions (16).

To date, only the respiratory arsenate reductase (DAsR) from $C$. arsenatis has been purified and characterized (31). A periplasmic enzyme, the DAsR is composed of an 87-kDa polypeptide and a 29-kDa polypeptide. It is a heterodimer with a native molecular mass of $123 \mathrm{kDa}$. The active site is located in the large subunit and contains molybdenum. $\mathrm{N}$-terminal amino acid sequence analysis also revealed a putative $[\mathrm{Fe}-\mathrm{S}]$ cluster binding site. The small subunit contains at least one [Fe-S] cluster and is believed to be involved in electron transfer and anchoring. A small-molecular-mass $c$-type cytochrome has also been linked to the enzyme complex. The enzyme exhibits a high degree of specificity for arsenate and has a $K_{\mathrm{m}}$ of $300 \mu \mathrm{M}$. How arsenate reduction in the periplasm is coupled to the generation of the proton motive force is unclear, however, as arsenate reduction should consume protons and electrons $\left(\mathrm{HAsO}_{4}{ }^{2-}+4 \mathrm{H}^{+}+2 \mathrm{e}^{-} \rightarrow \mathrm{HAsO}_{2}+\right.$ $2 \mathrm{H}_{2} \mathrm{O}$ ), that are initially generated from the oxidation of a substrate like hydrogen $\left(\mathrm{H}_{2} \rightarrow 2 \mathrm{H}^{+}+2 \mathrm{e}^{-}\right)$. More studies are needed to understand the details of the electron transfer pathway to arsenate in this organism, and we refer the reader to Chapter 12 for a more comprehensive discussion of this system. 
Work continues on the purification and characterization of the DAsR from $S$. barnesii. This effort has been complicated for two reasons. The first is that the enzyme complex is membrane bound and not readily solubilized. The second is the presence of a membrane-bound bidirectional hydrogenase (17). Initial attempts at purifying the complex were made using native preparative gel electrophoresis. The gels were developed using methyl viologen as the artificial electron donor and arsenate as the electron acceptor. Two activities were observed, a complex with low mobility that barely migrated into the gel, and a complex with high mobility that migrated just above the dye front. The high-mobility complex contained polypeptides of 65,30 , and $22 \mathrm{kDa}$ (Fig. 4). N-terminal amino acid sequence indicated that the $65-\mathrm{kDa}$ polypeptide was the large subunit of a $\mathrm{Ni}$ Fe hydrogenase. This has since been confirmed by metals and Western blot analyses and activity assays (D. K. Newman et al., unpublished data). A BLAST search failed to find identities for either the 30- or 22-kDa polypeptides. Thus they are not the two additional subunits found in membrane-bound $\mathrm{Ni}-\mathrm{Fe}$ hydrogenases

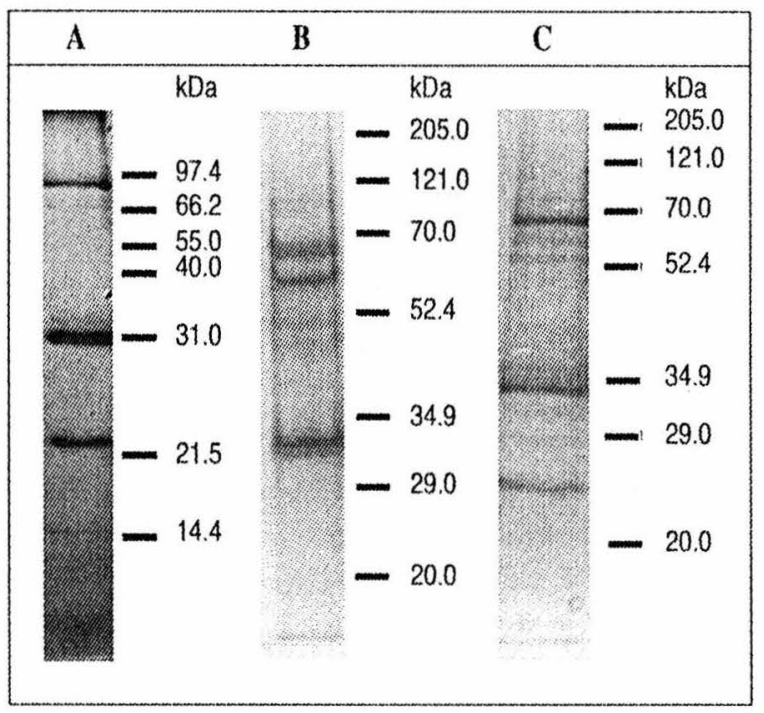

Figure 4 Protein complexes exhibiting arsenate reductase activity from Sulfurospirillum barnesii as achieved by using preparative gel electrophoresis (A) and hydroxyapatite column chromatography (B and C). (A) High-mobility complex containing polypeptides of 65,30 , and $22 \mathrm{kDa}$; (B) fraction that exhibited both hydrogenase and arsenate reductase activity; (C) fraction exhibiting only arsenate reductase activity. The 65-kDa polypeptide in all three complexes is the large subunit of the Fe-Ni hydrogenase. The molecular weight standards for each frame are given to the right of the gels. 
(i.e., $[\mathrm{Fe}-\mathrm{S}]$ cluster protein and cytochrome $b$ ). Furthermore, the N-terminal amino acid sequence of a 55-kDa polypeptide that was highly enriched in soluble fractions was identical to the 22-kDa N-terminal, suggesting that the native form of the 22-kDa polypeptide is a dimer.

Recent purification efforts employing column chromatography have yielded two fractions that exhibit arsenate reductase activity. Both fractions contain the large subunit of the Ni-Fe hydrogenase (Fig. 4). The presence of hydrogenase in the DAsR complex raises the question of its function: Does it donate electrons to a separate arsenate reductase, or does it directly reduce arsenate itself? Ni-Fe hydrogenases are known to donate electrons to a number of terminal reductases, including the fumarate reductase from Wolinella succinogenes (32). There is also a report of technicium reduction by a Ni-Fe hydrogenase from $E$. coli (33). In addition to Wolinella succinogenes, three other bacterial species closely related to $S$. barnesii also contain a similar Ni-Fe hydrogenase: Helicobacter pylori, Campylobacter jejuni, and Desulfovibrio desulfuricans. Not one of these organisms, however, respires arsenate. Both $C$. jejuni and D. desulfuricans do, however, exhibit arsenic resistance (B. Kail and A. Dawson, personal communication). It is tempting to speculate that the hydrogenase in these organisms may serve as the electron donor to the arsenate-reducing enzyme (be it for respiration or resistance), although this remains to be proven. What is clear, however, is that the detoxifying reductases are quite different from the respiratory ones, and that the respiratory reductases themselves are different from one another. This suggests that they arose from independent evolutionary lines.

\section{ARSENATE REDUCTION IN ANOXIC ECOSYSTEMS}

Discerning the contribution that micro-organisms make toward carrying out the reduction of arsenate in nature is greatly complicated by several chemical factors, which will be just briefly mentioned here. First, in addition to biological reduction, arsenate can also be reduced to arsenite by strong, naturally occurring reductants, such as sulfide, although this is generally favored at low $\mathrm{pH}$ rather than under neutral or alkaline conditions (where the reaction rate is slow) $(24,34)$. Conversely, a number of naturally occurring oxidants, such as $\mathrm{Fe}$ (III) and Mn(IV), can reoxidize As(III) back to As(V) (35). Secondly, arsenite formed in the presence of free sulfides at low to neutral $\mathrm{pH}$ will precipitate as arsenic trisulfide $\left(\mathrm{As}_{2} \mathrm{~S}_{3}\right)$, provided the concentration of sulfide is within the appropriate range (25). Finally, there is the question of sorption of both arsenic species to mineral phases. Arsenate adsorbs strongly to a number of common minerals, such as ferrihydrite, goethite, chlorite, and alumina, which constrains its mobility in aquifers, soils, and sediments. This is a complicated, $\mathrm{pH}$-dependent phenomenon (36). Phosphate has chemical properties similar to arsenate and is a common anion 
present in nutrient-rich systems, such as aquifers underlying P-fertilized agricultural soils. Phosphate can therefore compete with arsenate for these adsorptive sites, thereby making arsenate more mobile under conditions of phosphate abundance. Arsenite is more toxic and generally more mobile in nature than is arsenate. Nonetheless, arsenite still has significant sorptive interactions with certain minerals, such as goethite, which constrains its mobility in the environment (37).

Bearing the above constraints in mind, respiratory arsenate reduction can be discerned experimentally in arsenic-contaminated anoxic sediments (38). We offer the results of Dowdle et al. (39) as an instructive example of the complex biological and chemical dynamics of this process in natural systems. In these experiments, the reduction of arsenate required anoxia and was eliminated by autoclaving and by respiratory inhibitors like dinitrophenol and cyanide, thereby proving its hiological rather than chemical mode of action. Reduction was speeded by certain electron donors, such as $\mathrm{H}_{2}$, lactate, or glucose, and mineralization of $\left[{ }^{14} \mathrm{C}\right]$ acetate could be linked to the presence of arsenate. These results pointed to direct reduction via an anaerobic respiratory process, rather than an indirect reduction via formation of a potent reductant (e.g., sulfide) by bacterial activity. Recovery of arsenite was enhanced by the presence of added electron donors, suggesting that binding of arsenite to ferrihydrite could be eliminated by the latter's reduction to $\mathrm{Fe}$ (II) (Fig. 5). Potentially competing electron acceptors (sulfate) or periodic table neighbors (phosphate) did not significantly affect arsenate removal rates (Fig. 6). However, the poor recoveries of arsenite in these experiments point to the precipitation or binding of this reduced product to other sorptive sites. Thus, while sulfate did not inhibit removal of arsenate ions from solution (Fig. 6b), the recovery of arsenite was less than in the controls, presumably due to the formation of insoluble arsenic trisulfides associated with sulfate reduction $(25,26,40)$. Likewise, Fe(III) sorbed arsenate (Fig. 6d), while $\mathrm{Mn}$ (IV) probably sorbed arsenite (Fig. 6c). Nitrate appeared to slow the removal of arsenate and totally prevented the accumulation of arsenite (Fig. 6d). This was probably due to its action as a competitive sink for electrons with arsenate coupled with the ability of nitrate to achieve the reoxidation of arsenite to arsenate. Experiments with chloramphenicol in nitrate-respiring sediments revealed that a de novo synthesis of protein was required in order to reduce arsenate, which suggested that the arsenate was not being reduced by the nitrate reductase, but rather by a specific arsenate reductase that required induction. Molybdate did not inhibit any arsenate reduction while tungstate did (Fig. 7). This suggested that sulfate reducers were not responsible (they would have been inhibited by both molybdate and tungstate), but rather that the reduction was mediated by a molybdenumcontaining enzyme, like that found for the respiratory arsenate reductase of $C$. arsenatis (31).

The above example reveals that the activity of respiratory arsenate reducers can be elicited when arsenate anions are present at high concentrations $(\sim 10$ 


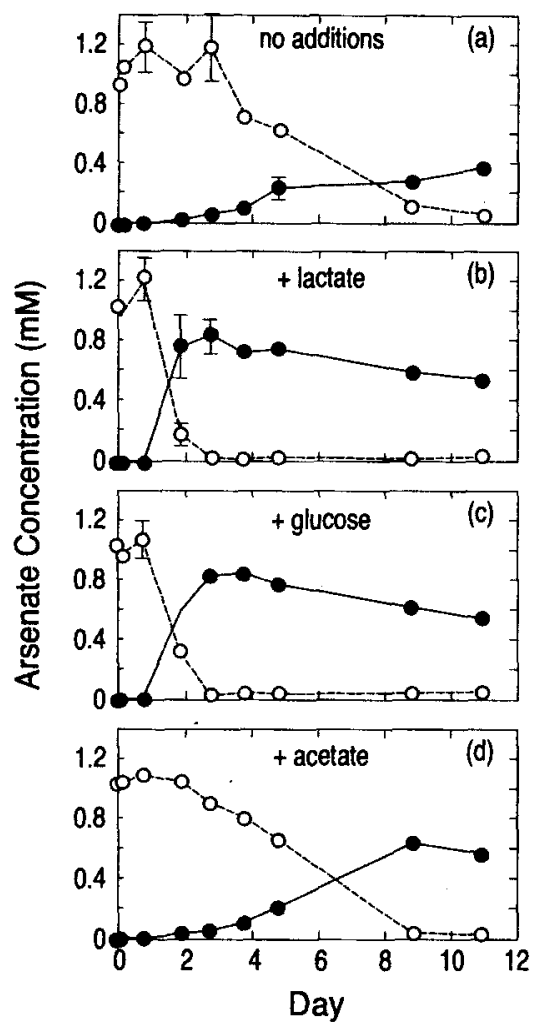

Figure 5 Effect of electron donors on the reduction of arsenate $(O)$ to arsenite $(\bullet)$ in anoxic estuarine sediment slurries incubated (a) without additions, (b) with lactate, (c) with glucose, and (d) with acetate. (From Ref. 39.)

$\mathrm{mM}$ ) in the aqueous phase of experimental systems. It is important to recognize, however, that the behavior of this consortium (e.g., with respect to inhibition by alternative electron acceptors and other compounds) reflects merely the microbial population at this particular site and cannot be generalized. Indeed, other studies with field sediment/soil slurries have suggested that a significant fraction of the organisms responsible for microbial arsenate reduction in different locales include sulfate reducers (38) (J. Sharp and D. K. Newman, unpublished data).

Much less is known about the ability of microbes to reduce arsenate at lower ambient concentrations, especially when it is associated with the solid rather than liquid phase, either as a component of an insoluble mineral or as an adsorbed anion. The mechanisms that have been investigated thus far include 


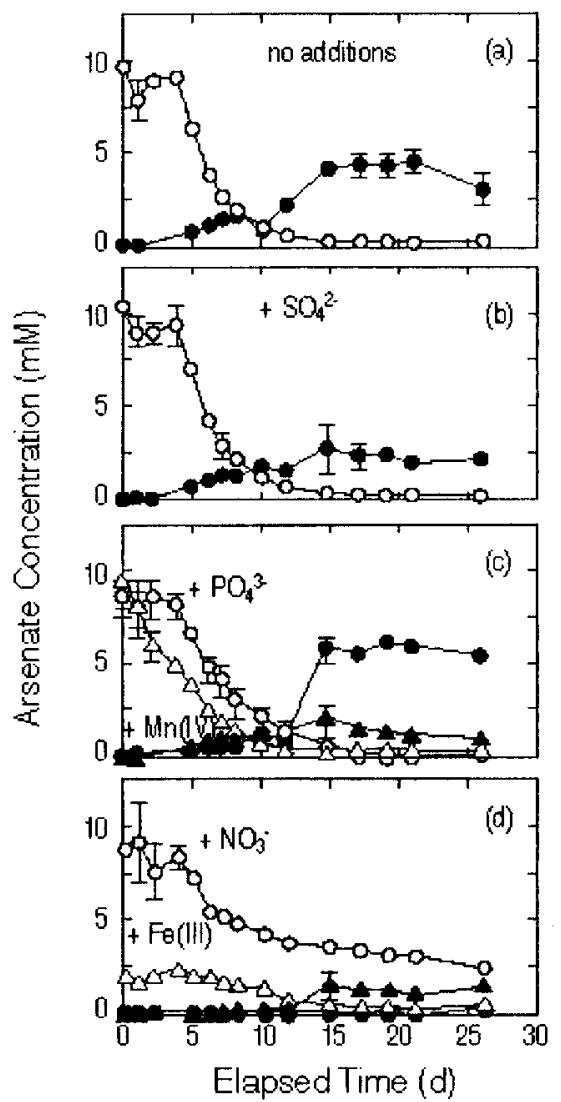

Figure 6 Effect of electron acceptors on the reduction of arsenate $(O)$ to arsenite $(\boldsymbol{O})$ in estuarine sediment slurries incubated (a) without additions. (b) with sulfate ions, (c) with phosphate or manganic ions, and (d) with nitrate or ferric ions. (From Ref. 39.)

hacterial destruction of the primary sorptive matrix (e.g., ferrihydrite), direct reduction of adsorbed arsenate, and reduction mediated by low-molecular-weight electron shuttles produced by bacteria (Fig. 8).

Cummings et al. (41) worked with the Fe(III)-respiring Shewanella alga and followed scorodite $\left(\mathrm{FeAsO} \mathrm{O}_{4} 2 \mathrm{H}_{2} \mathrm{O}\right)$ reductive dissolution in culture as well as by adding this bacterium to sterilized, metal-contaminated sediments. In both cases, this microbe was able to release arsenate into solution by breaking down the crystalline structure of scorodite via reducing Fe(III) to Fe(II). Presumably, this solubilized arsenate would then undergo bacterial reduction to arsenite by any arsenate respirers present in the natural flora. However, Newman et al. (24) 


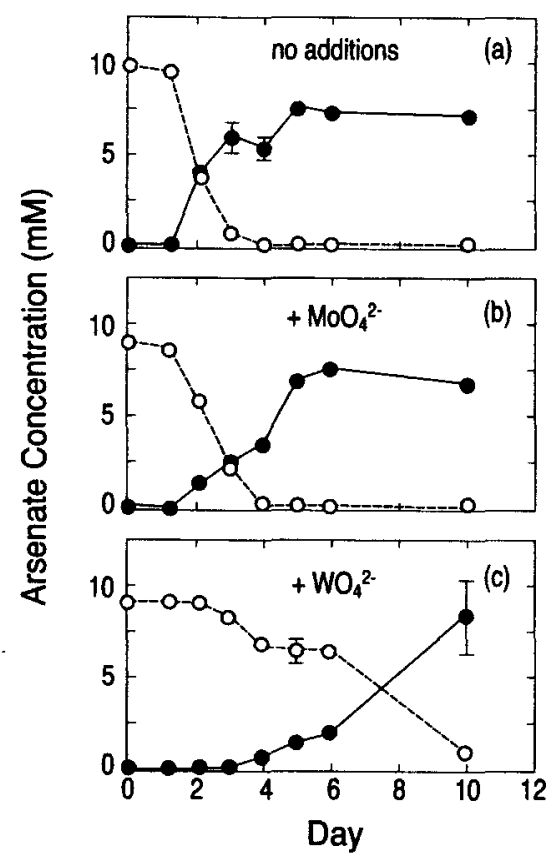

Figure 7 Effect of group VIA oxyanion inhibitors on the reduction of arsenate $(O)$ to arsenite (O) in estuarine sediments slurries incubated (a) without additions, (b) with molybdate, and (c) with tungstate. (From Ref. 39.)

found that Desulfotomaculum auripigmentum was able to directly reduce the arsenate contained in scorodite, thereby releasing As(III) into solution and achieving growth as well. Ahmann et al. (42) working with ferric arsenate-amended sediments from the As-contaminated Aberjona watershed were able to demonstrate the microbially catalyzed release of both Fe(II) and As(III) by the natural microbiota, as well as by adding $S$. arsenophilum (strain MIT-13) or an As(V)-respiring enrichment to sterilized sediments. By comparison, addition of the $\mathrm{Fe}$ (III)-respiring Geobacter metallireducens resulted in little detectable As(III) production.

Most of the above examples followed the dissolution of arsenic in complex sediment systems amended with scorodite and cultures of iron- or arsenate-respiring bacteria. More work was needed with simpler, defined systems to unravel the biological mechanisms from the adsorptive chemical phenomena. Zobrist et al. (43) studied the reductive dissolution of ferrihydrite that was coprecipitated with arsenate. Sulfurospirillum barnesii was the organism of choice because it respires both Fe(III) and As(V). Washed cell suspensions of S. barnesii simultaneously reduced Fe(III) as well as As(V) (Fig. 9). However, As(III) still had a 


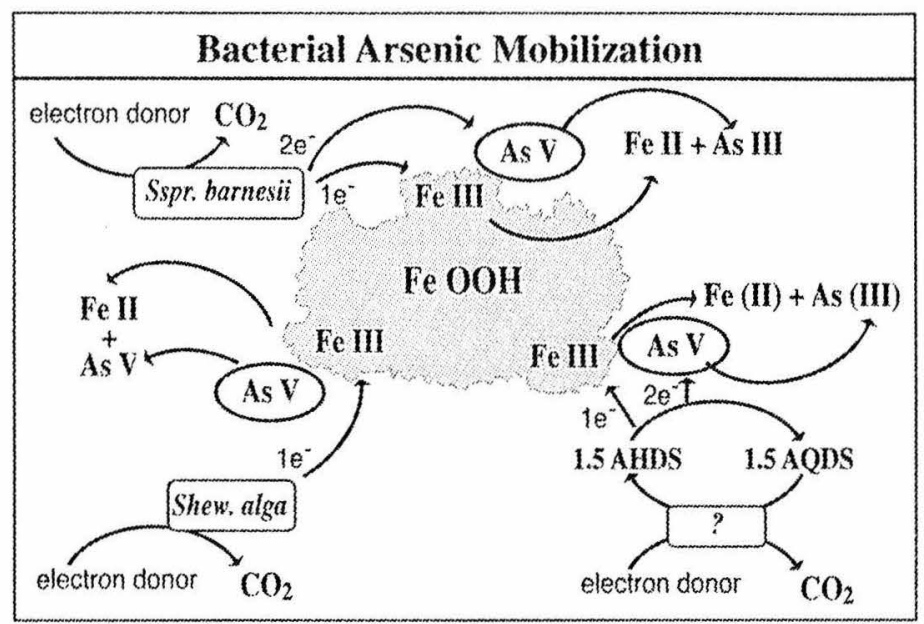

Figure 8 Schematic representation of three possible microbial mechanisms for mobilization of arsenic oxyanions adsorbed to ferrihydrite surfaces by respiratory reduction. Bottom left: Shewanella alga reduces $\mathrm{Fe}(\mathrm{III})$ to $\mathrm{Fe}(\mathrm{II})$, thereby releasing $\mathrm{As}(\mathrm{V})$ into solution (41). Lower right: bacterially reduced electron "shuttle" molecules pass electrons to solid-phase $\mathrm{As}(\mathrm{V})$ and $\mathrm{Fe}(\mathrm{III})$ (48). Top: Sulfurospirillum barnesii directly reduces both $\mathrm{As}(\mathrm{V})$ and $\mathrm{Fe}(\mathrm{III})(43)$.

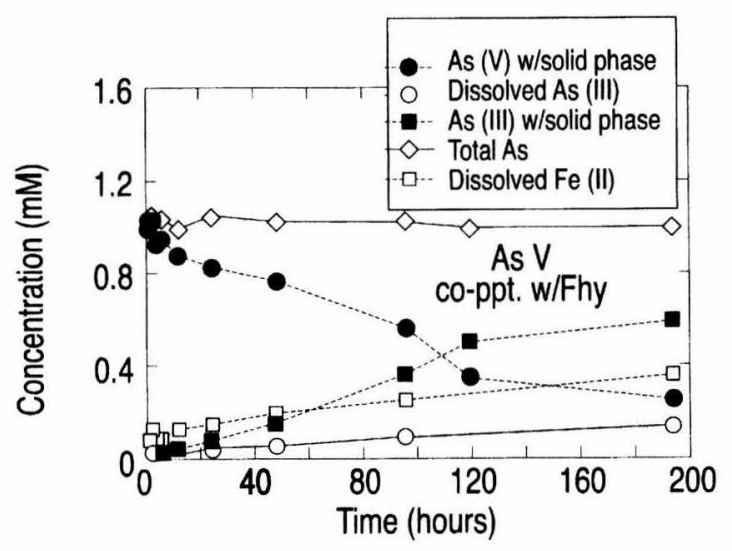

Figure 9 Reduction of $\mathrm{As}(\mathrm{V})$ and $\mathrm{Fe}(\mathrm{III})$ in aggregates of arsenate coprecipitated with ferrihydrite by cell suspensions of Sulfurospirillum barnesii. (From Ref. 43.) 
strong capacity for adsorption to the remaining unreacted ferrihydrite, and although there was significant mobilization of arsenite into the aqueous phase, most of the As(III) that was formed remained associated with the solid phase. This interpretation was verified in abiotic experiments by the observation that the coprecipitated ferrihydrite still had a sorptive capacity for As(III) but did not desorb As(V) from its matrix. Another experiment was conducted using As(V) coprecipitated with $\mathrm{Al}(\mathrm{OH})_{3}$ (Fig. 10). In this case, the respiratory reduction of sorbed As(V) was balanced by the increase in levels of As(III), but because abiotic experiments showed that As(III) does not adsorb to this mineral, all the As(III) was found in solution with none occurring in association with the solid phase. However, because $S$. barnesii does not reduce $\mathrm{Al}(\mathrm{III})$, the $\mathrm{Al}(\mathrm{OH})_{3}$ matrix was not broken down and the interior coprecipitated $\mathrm{As}(\mathrm{V})$ was unavailable for continued respiratory reduction. This resulted in less overall $\mathrm{As}(\mathrm{V})$ reduction than was the case for ferrihydrite (see Fig. 9).

These experiments pointed out that respiratory reduction of $\mathrm{As}(\mathrm{V})$ sorbed to solid phases can indeed occur in nature, but its extent and the degree of mobilization of the As(III) product is constrained by the type of minerals present in a given system. What remains unclear is whether micro-organisms can actually reduce $\mathrm{As}(\mathrm{V})$ while it is attached to the mineral surface, or if they attack a monolayer of aqueous $\mathrm{As}(\mathrm{V})$ that is in equilibrium with the As(V) adsorbed onto the surface layer. If, as is the case for dissimilatory metal-reducing bacteria such as Geobacter sulfurreducens and Shewanella oneidensis $(44,45)$, components of the electron transport chain are localized to the outer-membrane of some arsenaterespiring bacteria, direct reductive dissolution of insoluble arsenate minerals may be possible by attached bacteria. Too little is known at present about the topology

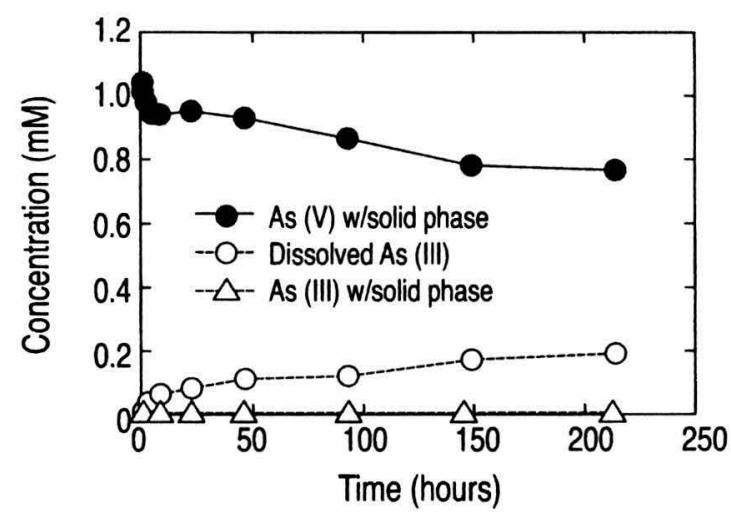

Figure 10 Reduction of $\mathrm{As}(\mathrm{V})$ in aggregates of arsenate coprecipitated with aluminum hydroxide by cell suspensions of Sulfurospirillum barnesii. (From Ref. 43.) 
of the arsenate reductases, however, to resolve this question, and further research is merited. It is noteworth, however, that Langer and Inskeep (46) did not observe reductive dissolution of $\mathrm{As}(\mathrm{V})$ adsorbed onto ferrihydrite in the presence of an unidentified glucose-fermenting organism. This organism reduced $\mathrm{As}(\mathrm{V})$ by the detoxification rather than by the respiratory mechanism, and proved capable of only reducing $\mathrm{As}(\mathrm{V})$ that was dissolved in the aqueous phase. Although the cellular location of the arsC-type reductase is not known for this isolate, in wellstudied bacterial systems they are associated with the cytoplasm rather than the membrane (1). The hypothesis that reduction of insoluble arsenate minerals requires surface-associated proteins can be tested by identifying the cellular location of arsenate reductases in organisms that grow on such minerals.

Another possible mechanism for reductive dissolution of arsenate adsorbed onto mineral surfaces would involve low-molecular-weight organic substances that act as electron shuttles. These molecular "shuttles" have been found to act as electron acceptors for anaerobic growth of diverse metal-respiring bacteria (47), and can transfer these electrons to insoluble, oxidized metals thereby achieving their dissolution $(48,49)$. Bacteria are known to utilize exogenous humic substances in such a capacity (47), and it has also been proposed that some may even excrete their own shuttling compounds (50), which would enable electron transfer to mineral matrices that would otherwise be inaccessible. A reduced humic analog, anthrahydroquinone-2,6-disulfonate (AHDS), is commonly used as a model compound for such investigations. It was unable to reduce soluble $\mathrm{As}(\mathrm{V})$ directly, although it could also serve as an electron donor for Wollinella succinogenes and $S$. barnesii to achieve the reduction of arsenate directly $(51)$. However, no work has been done on the ability of AHDS to reduce As(V) adsorbed onto or coprecipitated with minerals such as ferrihydrite, making this an area still ripe for future investigations.

The presence of high concentrations of arsenic in the environment results from anthropogenic sources (e.g., mine tailings, pesticide production, animal hide tanning) as well as from natural sources (weathering of arsenic minerals, hydrothermal waters). Some regions of the United States, such as the Carson Desert of western Nevada, have a particularly high natural abundance of arsenic, with some of its shallow groundwaters exhibiting concentrations as high as $\sim 13 \mu \mathrm{M}$ $(52,53)$. Serious human health problems are common in the population that ingests water from these aquifers as their primary drinking supply (54). In order to determine if the arsenic contained in these groundwaters is a consequence of in situ reduction of $\mathrm{As}(\mathrm{V})$ to $\mathrm{As}(\mathrm{III})$ occurring in aquifer materials, an assay of arsenate reductase activity is needed. Fortunately, ${ }^{73} \mathrm{As}(\mathrm{V})$ is a commercially available, gamma-emitting radiotracer $\left(t_{1 / 2}=80.3\right.$ days). In theory, its use would allow investigations of arsenic biogeochemistry to be conducted at ambient concentrations of this element. However, preliminary attempts to employ this radiotracer in aquifer sediments have been unsuccessful. This failure has been due, 

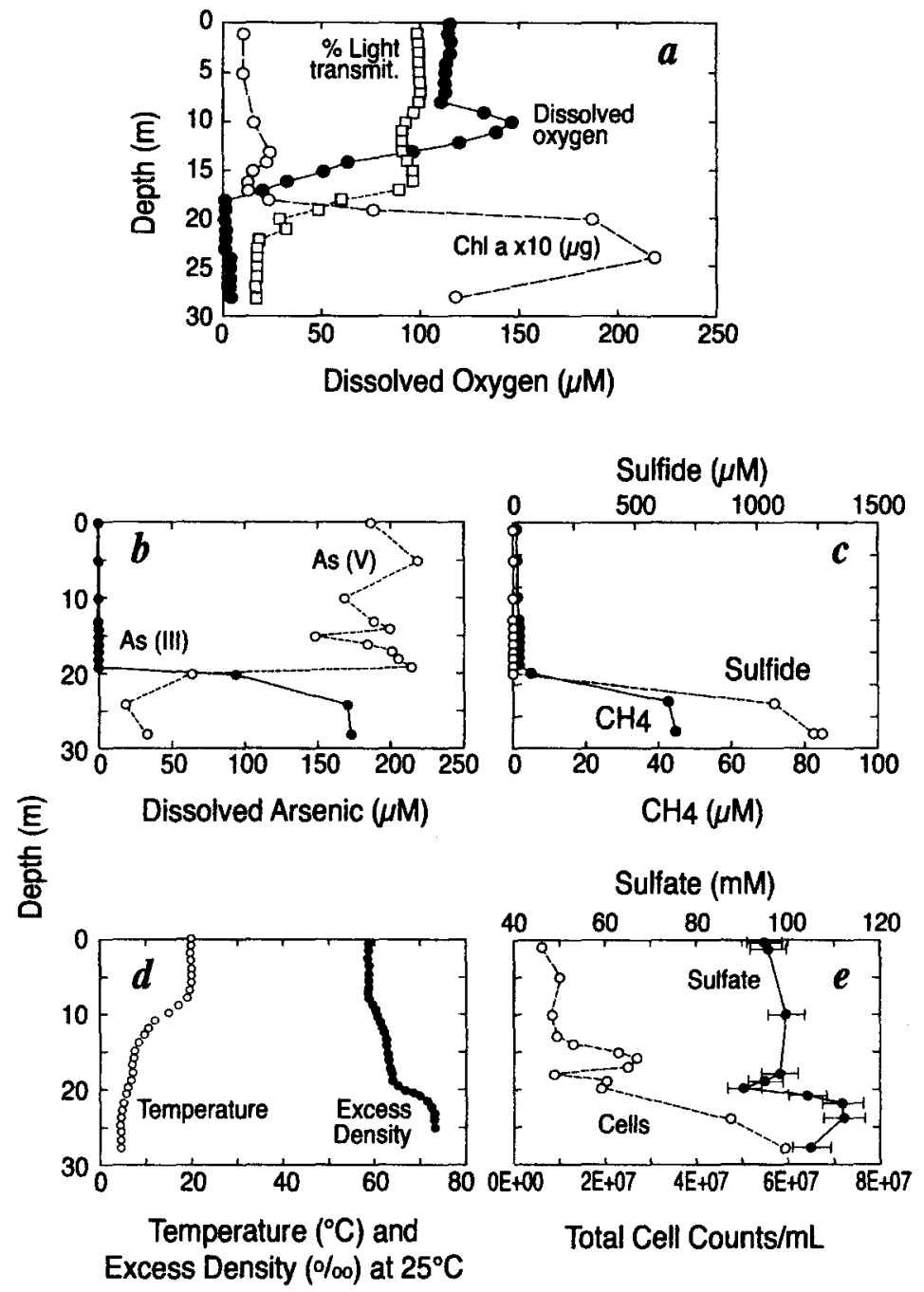

Figure 11 Vertical depth profiles taken in July, 1999 of various physical, chemical, and biological properties of Mono Lake, California, when the lake was in a meromictic condition. (a) Dissolved oxygen, light transmissivity, and chlorophyll a content; (b) arsenate and arsenite; (c) methane and sulfide; (d) temperature and density; (e) direct counts of bacterial cells and sulfate. (From Ref. 57.) 


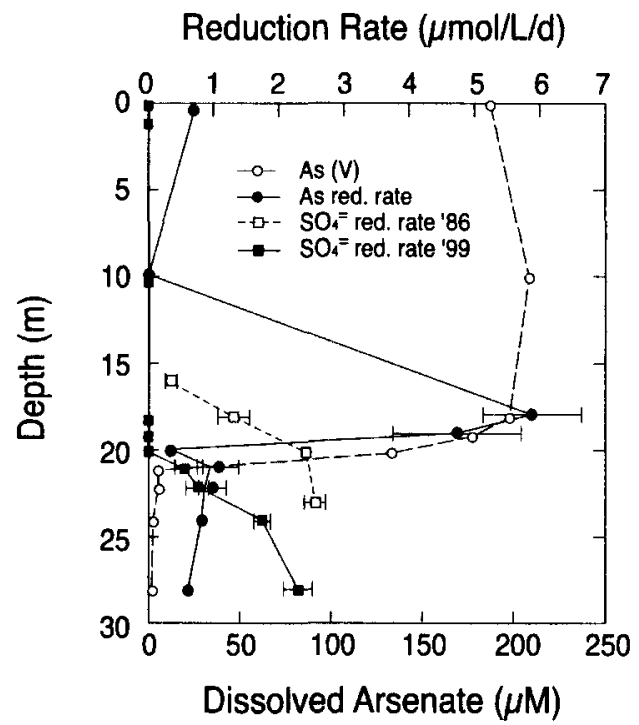

Figure 12 Vertical depth profiles of arsenate with rates of respiratory arsenate and sulfate reduction in the water column of meromictic Mono Lake. California, made during October, 1999. Sulfate-reduction profiles from the last period of meromixis (1986) when the lake was $4 \mathrm{~m}$ shallower are shown for comparison. (From Ref. 57.)

in part, to the differential chemical sorptive behavior of both arsenate and arsenite with the various types of solid matrices assayed, which results in qualitative rather than quantitative recoveries of the two species (P. Dowdle and R. Oremland, unpublished data). The nonquantitative recovery of these two species makes employment of this radiotracer as yet unsuitable for the determination of rate constants in sediments, soils, and aquifer materials.

Anoxic water samples, because they contain little in the way of particles, are far easier than aquifer materials to develop radioassays for the measurement of arsenate reduction. Arsenic speciation quantitatively changes from arsenate to arsenite with vertical transition from the surface oxic waters to the anoxic bottom depths of stratified lakes and ljords $(55,56)$. This also occurs in Mono Lake, California (57), a transiently meromictic, alkaline $(\mathrm{pH}=9.8)$, and hypersaline (salinity $=70-90 \mathrm{~g} / \mathrm{L}$ ) soda lake located in eastern California (Fig. 11). The combined effects of hydrothermal sources coupled with evaporative concentration have resulted in exceptionally high $(\sim 200 \mu \mathrm{M})$ dissolved arsenate concentrations in its surface waters. Haloalkaliphilic arsenate-respiring bacteria have been isolated from the lake sediments (26). and sulfate reduction, achieved with 
$\left[{ }^{35} \mathrm{~S}\right]$ sulfate radiotracer, had been measured in the lake's anoxic waters during a past episode of meromixis in 1986. In situ measurements made with ${ }^{73} \mathrm{As}(\mathrm{V})$ during 1999 revealed that arsenate reduction was a significant microbial activity in the water column of the lake (57), with the highest activity occurring at a depth of $18 \mathrm{~m}$ (Fig. 12). Much lower activity occurred at depths below $20 \mathrm{~m}$, mainly because the arsenate pools were so low $(<10 \mu \mathrm{M})$ even though rate constants were high $\left(\sim 0.3\right.$ day $\left.^{-1}\right)$. Although sulfate reduction rates increased with depth below $20 \mathrm{~m}$, the abundance of arsenate respirers was 10 -fold higher than that of sulfate reducers as determined by MPN (most probable number) methods. An important finding was that microbial arsenate respiration in the water column could account for as much as $14 \%$ mineralization of annual primary productivity, with sulfate reduction accounting for as much as $41 \%$. This finding was the first report that arsenate respiration can make a significant contribution to the carbon cycle of an ecosystem.

\section{CONCLUSIONS}

The exciting discovery of the process of respiratory reduction of arsenate by prokaryotes has thus far resulted in identification of this unique means of respiration in seven new and highly diverse species of Eubacteria, and in one new and one previously isolated species of Crenoarchaea. Relatively little is known as yet about the respiratory arsenate reductases of these organisms, since they have only been preliminarily characterized in C. arsenatis and in S. barnesii. Clearly, more detailed biochemical, biophysical, and genetic characterization of these DAsR enzymes from these organisms as well as from some of the extremophiles capable of growing on arsenate is needed. Such work may eventually determine if these enzymes were derived from a common ancestral gene and propagated through microbial communities by such means as lateral gene transfer, whether they evolved from detoxifying ars $C$ reductases (or vice versa), or if they arose independently in several distantly related taxonomic groups of prokaryotes by convergent evolution. Regardless of their origin or their biochemical structure, microbial enzymes that reduce arsenate appear to play an important role in the mobility of this element in aqueous matrices and in the formation and destruction of various minerals. In addition to more isolations and enzymological studies, there is a need for future research that is oriented to the adaptation of molecular tools based on polymerase chain reaction technology to identify natural assemblages of active arsenate-respiring micro-organisms in the environment. When such techniques are coupled with sensitive bioassays for DAsR using ${ }^{73}$ As, they will broaden our understanding of the significance of arsenate reduction in a number of anoxic ecosystems, such as sediments, hot springs, freshwater and marine systems, as well as in geological materials. 


\section{ACKNOWLEDGMENTS}

We thank Prof. H. L. Ehrlich and Prof. L. Young for helpful comments on an carlier draft of this manuscript.

\section{REFERENCES}

1. C Cervantes, G Ji, JL Ramirez, S Silver. Resistance to arsenic compounds in microorganisms. FEMS Microbiol Rev 15:355-367, 1994.

2. S Silver, $M$ Walderhaug. Gene regulation of plasmid- and chromosome-determined inorganic ion transport in bacteria. Microbiol Rev 56:195-228, 1992.

3. NN Rao. A Torriani. Molecular aspects of phosphate transport in Escherichia coli. Mol Microbiol 4:1083-1090. 1990.

4. GR Willsky, MH Malamy. Effect of arsenate on inorganic phosphate transport in Escherichia coli. J Bacteriol 144:366-374. 1980.

5. DH Nies, S Silver. Ion efflux systems involved in bacterial metal resistances. J Indust Microhiol 14:186-199, 1995.

6. DJH Phillips. The chemical forms of arsenic in aquatic organisms and their interrelationships. In: JO Nriagu, ed. Arsenic in the Environment. Part I: Cycling and Characterization. New York: John Wiley \& Sons, 1994, pp 263-288.

7. KJ Reimer. The methylation of arsenic in marine sediments. Appl Organomet Chem 3:475-490, 1989.

8. I Koch, L Wang, CA Ollson. WR Cullen. KJ Reimer. The predominance of inorganic arsenic species in plants from Yellowknife, Northwest Territories, Canada. Environ Sci Technol 34:22-26. 2000.

9. K Hanaoka, H Yamamoto. K Kawashima. S Tagawa, T Kaise. Ubiquity of arsenobetaine in marine animals and degradation of arsenobetaine by sedimentary microorganisms. Appl Organometal Chem 2:371-376, 1988.

10. R Ciulla, MR Diaz, BF Taylor, MF Roberts, Organic osmolytes in aerobic bacteria from Mono Lake, an alkaline, moderately hypersaline environment. Appl Environ Microbiol 63:220-226. 1997.

11. EH Larsen, CR Quétel. R Munoz, A Fiala-Medioni, OFX Donard. Arsenic speciation in shrimp and mussel from the Mid-Atlantic hydrothermal vents. Marine Chem 57: $341-346.1997$.

12. JM Neff. Ecotoxicology of arsenic in the marine environment. Environ Toxicol Chem 16:917-927. 1997.

13. GM King. Utilization of hydrogen. acetate. and "non-competitive" substrates by methanogenic bacteria in marine sediments. Geomicrobiol J 3:275-306, 1984.

14. LCD Anderson. KW Bruland. Biogeochemistry of arsenic in natural waters: The importance of methylated species. Environ Sci Technol 25:420-427, 1991.

15. D Ahmann. AL Roberts, LR Krumholz, FMM Morel. Microbe grows by reducing arsenic. Nature 371:750. 1994.

16. DK Newman, D Ahmann. FMM Morel. A brief review of microbial arsenate respiration. Geomicrobiol J 15:25.5-268. 1998. 
17. JF Stolz, RS Oremland. Bacterial respiration of arsenic and selenium. FEMS Microbiol Rev 23:615-627, 1999.

18. RS Oremland, JF Stolz. Dissimilatory reduction of selenate and arsenate in nature. In DR Lovley, ed. Environmental Microbe-Metal Interactions, Washington DC: ASM Press, 2000, pp 199-224.

19. R Nickson, J MacArthur, W Burgess, KM Ahmed, P Ravenscroft, M Rahman. Arsenic poisoning of Bangaladesh groundwater. Nature 395:338, 1998.

20. JF Stolz, DJ Ellis. J Switzer Blum. D Ahmann, DR Lovley, RS Oremland. Sulfurospirillum barnesii $\mathrm{sp}$. nov., Sulfurospirillum arsenophilum sp. nov., and the Sulfurospirillum clade in the Epsilon Proteobacteria. Int J Syst Bacteriol 49:1177-1180, 1999.

21. RS Oremland, J Switzer Blum, CW Culbertson, PT Visscher, LG Miller, P Dowdle, FE Strohmaier. Isolation, growth, and metabolism of an obligately anaerobic, selenate-respiring bacterium, strain SES-3. Appl Environ Microbiol 60:3011-3019, 1994.

22. AM Laverman, J Switzer Blum, JK Schaefer, EJP Philips, DR Lovley, RS Oremland. Growth of strain SES-3 with arsenate and other diverse electron acceptors. Appl Environ Microbiol 61:3556-3561, 1995.

23. JM Macy, K Nunan, KD Hagen. DR Dixon, PJ Harbour, M Cahill, LI Sly. Chrysiogenes arsenatis gen. nov., sp. nov., a new arsenic-respiring bacterium isolated from gold mine wastewater. Int J Syst Bacteriol 46:1153-1157, 1996.

24. DK Newman, EK Kennedy, JD Coates, D Ahmann, DJ Ellis, DR Lovely, FMM Morel. Dissimilatory arsenate and sulfate reduction in Desulfotomaculum auripigmentum sp. nov. Arch Microbiol 168:380-388, 1997.

25. DK Newman, TJ Beveridge. FMM Morel. Precipitation of arsenic trisulfide by $D e$ sulfotomaculum auripigmentum. Appl Environ Microbiol 63:2022-2028, 1997.

26. J Switzer Blum, A Burns Bindi, J Buzelli, JF Stolz, RS Oremland. 1998. Bacillus arsenicoselenatis, sp. nov., and Bacillus selenitireducens sp. nov.: Two haloalkaliphiles from Mono Lake, California that respire oxyanions of selenium and arsenic. Arch Microbiol 171:19-30, 1998.

27. JM Macy, JM Santini, BV Pauling. AH O'Neill, LI Sly. Two new arsenate/sulfatereducing bacteria: Mechanisms of arsenate reduction. Arch Microbiol 173:49-57, 2000.

28. R Huber, M Sacher, A Vollmann, H Huber, D Rose. Respiration of arsenate and selenate by hyperthermophilic Archaea. Syst Appl Microbiol 23:305-314, 2000.

29. DK Nordstrom, C.N. Alpers. Negative $\mathrm{pH}$, efflorescent mineralogy, and consequences for environmental restoration at the Iron Mountain Superfund site, California. Proc Nat1 Acad Sci USA 96:3455-3462.

30. KJ Edwards, PL Bond, TM Gihring, JF Banfield. A new iron-oxidizing, extremely acidophilic archaea is implicated in an extreme acid mine drainage generation. Science 287:1796-1799, 2000.

31. T Krafft, JM Macy. Purification and characterization of the respiratory arsenate reductase of Chrvsiogenes arsenatis. Eur J Biochem 255:647-653, 1998.

32. R Gross, J Simon, F Theis, A Kroeger. Two membrane anchors of Wolinella succinogenes hydrogenase and their function in fumarate and polysulfide respiration. Arch Microbiol 170:50-58, 1997. 
33. JR Lloyd, JA cole, LE Macaskie. Reduction and removal of heptavalent technicium from solution by Escherichia coli. J Bacteriol 179:2014-2021. 1997.

34. JA Cherry, AU Shaikh. DE Tallman, RV Nicholson. Arsenic species as an indicator of redox conditions in groundwater. J Hydrol 4.3:37.3-392, 1979.

35. DW Oscarson, PM Hunag, C Defosse, A Herbillon. Oxidative power of Mn(IV) and Fe(HI) oxides with respect to As(IIl) in terrestrial and aquatic environments. Nature 91:50-51, 1981.

36. CC Fuller, JA Davis. GA Waychunas. Surface chemistry of ferrihydrite. Part 2: Kinetics of arsenate adsorption and coprecipitation. Geochim Cosmochim Acta 57: 2271-2282, 1993.

37. BA Manning, SE Fendorf', S. Goldberg. Surface structures and stability of arsenic (III) on goethite: Spectroscopic evidence for inner-sphere complexes. Environ Sci Technol 32:2383-2388. 1998.

38. JM Harrington, SE Fendorf, RF Rosenzweig. Biotic generation of arsenic (III) in metal(loid)-contaminated freshwater lake sediment. Environ Sci Technol 32:24252430. 1998.

39. PR Dowdle, AM Laverman. RS Oremland. Bacterial reduction of arsenic (V) to arsenic (II) in anoxic sediments. Appl Environ Microbiol 62:1664-1669. 1996.

40. KA Rittle, JI Drever. PJS Colberg. Precipitation of arsenic during bacterial sulfate reduction. Geomicrobiol J 1.3:1-11, 1995.

41. DE Cummings, F Caccovo Jr.. S Fendorf. RF Rosenzweig. Arsenic mobilization hy the dissimilatory Fe(III)-reducing hacterium Shewanella alga BrY. Environ Sci Technol 33:723-729. 1999.

42. D Ahmann, LR Krumholz, H Hemond, DR Lovley, FMM Morel. Microbial mobilization of arsenic from sediments of the Aberjona Watershed. Environ Sci Technol 31:2923-2930, 1997.

43. J Zobrisı, PR Dowdle, JA Davis, RS Oremland. Mobilization of arsenite by dissimilatory reduction of adsorbed arsenate. Env Sci Technol 34:4747-4753. 2000.

44. S Gaspard, F Vazquez, and C Holliger. Localization and solubilization of the iron (III) reductase of Geobacter sullurreducens. J Bacteriol 64:3188-3194.

45. AS Beliaev. D Saffarini. Shewanella putrefaciens mtrB encodes an outer membrane protein required for $\mathrm{Fe}(\mathrm{III})$ and Mn(IV) reduction. J Bacteriol 180:6292-6297, 1998.

46. HW Langer. WP Inskeep. Microbial reduction of arsenate in the presence of ferrihydrite. Environ Sci Technol 34:3131-31,36, 2000.

47. DR Lovley, JI) Coates, EL Blunt-Harris, EJP Philips, JC Woodward. Humic substances as electron acceptors for microbial respiration. Nature 382:445-448, 1996.

48. DR Lovley, JL Fraga, EL Blunt-Harris, LA Hayes, EJP Hilips, JD Coates. Humic substances as a mediator for microbially catalyzed metal reduction. Acta Hydrochim Hydrobiol 26:152-157, 1998.

49. KP Nevin, DR Lovley. Potential for nonenzymantic reduction of Fe(III) via electron shuttling in subsurlace sediments. Environ Sci Technol 34:2472-2478, 2000.

50. DK Newman, R Kolter. A role for excreted quinones in extracellular electron transfer. Nature 405:94-97, 2000.

51. DR Lovley, JL Fraga, JD Coates, EL Blunt-Harris. Humics as an electron donor for anaerobic respiration. Environ Microbiol 1:89-98, 1999. 
52. AH Welch, MS Lico. Factors controlling As and $U$ in shallow ground water, southern Carson Desert, Nevada. Appl Geochem 13:521-539, 1998.

53. AH Welch, DB Westjohn, DR Helsel, RB Wanty. Arsenic in ground water of the United States: Occurrence and geochemistry. Groundwater 38:589-604, 2000.

54. PA Glancy. Geohydrology of the basalt and unconsolidated sedimentary aquifers in the Fallon area, Churchill County, Nevada. U.S. Geological Survey Water-Supply Paper 2263, 1986.

55. ML Peterson, R Carpenter. Biogeochemical processes affecting total arsenic and arsenic species distributions in an intermittently anoxic fjord. Marine Chem 12:295$321,1983$.

56. P Seyler, JM Martin. Biogeochemical processes affecting arsenic speciation in a permanently stratfieid lake. Environ Sci Technol 23:1258-1263, 1989.

57. RS Oremland, PR Dowdle, S Hoeft, JO Sharp, JK Schaefer, LG Miller, J Switzer Blum, RL Smith, NS Bloom, D Wallschlaeger. Bacterial dissimilatory reduction of arsenate and sulfate in meromictic Mono Lake, California. Geochim Cosmochim Acta 64:3073-3084, 2000. 